\title{
Mineral Phases and Release Behaviors of As in the Process of Sintering Residues Containing As at High Temperature
}

\author{
Xingrun Wang, ${ }^{1}$ Fengsong Zhang, ${ }^{1}$ and Zexi Nong ${ }^{1,2}$ \\ ${ }^{1}$ State Key Laboratory of Environmental Criteria and Risk Assessment, Chinese Research Academy of Environmental Sciences, \\ Beijing 100012, China \\ ${ }^{2}$ School of Chemical \& Environmental Engineering, China University of Mining \& Technology (Beijing), Beijing 100083, China
}

Correspondence should be addressed to Xingrun Wang; xingrunwang@gmail.com and Fengsong Zhang; zhangfs@craes.org.cn

Received 19 September 2013; Accepted 26 December 2013; Published 2 March 2014

Academic Editors: J. A. Grande and J. L. Zhou

Copyright (C) 2014 Xingrun Wang et al. This is an open access article distributed under the Creative Commons Attribution License, which permits unrestricted use, distribution, and reproduction in any medium, provided the original work is properly cited.

\begin{abstract}
To investigate the effect of sintering temperature and sintering time on arsenic volatility and arsenic leaching in the sinter, we carried out experimental works and studied the structural changes of mineral phases and microstructure observation of the sinter at different sintering temperatures. Raw materials were shaped under the pressure of $10 \mathrm{MPa}$ and sintered at $1000 \sim 1350^{\circ} \mathrm{C}$ for $45 \mathrm{~min}$ with air flow rate of $2000 \mathrm{~mL} / \mathrm{min}$. The results showed that different sintering temperatures and different sintering times had little impact on the volatilization of arsenic, and the arsenic fixed rate remained above $90 \%$; however, both factors greatly influenced the leaching concentration of arsenic. Considering the product's environmental safety, the best sintering temperature was $1200^{\circ} \mathrm{C}$ and the best sintering time was $45 \mathrm{~min}$. When sintering temperature was lower than $1000^{\circ} \mathrm{C}$, FeAsS was oxidized into calcium, aluminum, and iron arsenide, mainly $\mathrm{Ca}_{3}\left(\mathrm{AsO}_{4}\right)_{2}$ and $\mathrm{AlAsO}_{4}$, and the arsenic leaching was high. When it increased to $1200^{\circ} \mathrm{C}$, arsenic was surrounded by a glass matrix and became chemically bonded inside the matrix, which lead to significantly lower arsenic leaching.
\end{abstract}

\section{Introduction}

Arsenic pollution in solid wastes has aroused significant environmental concerns. arsenic is toxic and it may result in skin lesions and cancer of the liver, kidneys, and stomach $[1,2]$. Besides, it is hard to dispose arsenic. Arsenic is widely used in industrial plants and many ores are associated with arsenic, such as iron, gold, silver, mercury, copper, lead, and zinc minerals [3]. In China, about 30,000 t of arsenic enters into nonferrous metal smelting plant every year. Arsenic residues are mainly discharged into waters and simply stacked in piles, which has caused severe contamination in some areas, for example, Dasha river arsenic contamination in Henan province and Yangzonghai arsenic contamination in Yunnan province. Therefore, it is urgent to safely, stably, and harmlessly transform arsenic-containing wastes into resources.

In solid waste and contaminated soil, arsenic exists mostly as $\mathrm{As}(\mathrm{III})$ and $\mathrm{As}(\mathrm{V})$. As(III) is generally regarded as being more mobile and toxic than $\operatorname{As}(\mathrm{V})[4,5]$, while the latter is more easily adsorbed onto the surface of wastes. X-ray absorption near edge structure (XANES) spectroscopy has been increasingly used to determine the oxidation states in arsenic-containing wastes. Extended X-ray absorption fine structure (EXAFS) spectroscopy has been used to investigate the As contamination status of local environment [6-8].

Stabilization/solidification (S/S) processes are widely used to immobilize As in solid wastes [11]. Numerous researchers have studied the $S / S$ process to immobilize As by means of various $S / S$ agents such as cement [12-14], fly ash [15-17], and cement kiln dust [18, 19]. It has been reported that the $\mathrm{Ca}$-As precipitates were the major As immobilization mechanisms [20, 21]. Specific Ca-As precipitates, such as $\mathrm{Ca}_{3}\left(\mathrm{AsO}_{4}\right)_{2}, \mathrm{CaHAsO}_{3}[20,22]$, Ca-As$\mathrm{O}, \mathrm{Ca}_{4}(\mathrm{OH})_{2}\left(\mathrm{AsO}_{4}\right)_{2} \cdot 4 \mathrm{H}_{2} \mathrm{O}$, and $\mathrm{NaCaAsO}_{4} \cdot 7 \cdot 5 \mathrm{H}_{2} \mathrm{O}[16,19]$, have been reported as the compounds responsible for As immobilization in $S / S$ processes. The amount of solid waste is increased greatly after $\mathrm{S} / \mathrm{S}$ processes due to the adding of $\mathrm{S} / \mathrm{S}$ agents and the use of wastes after $\mathrm{S} / \mathrm{S}$ processes is also an urgent problem waiting for solution. 
TABLE 1: Chemical composition of experimental materials.

\begin{tabular}{lccc}
\hline & $\begin{array}{c}\text { Composition of } \\
\text { As-containing } \\
\text { residues (wt\%) }\end{array}$ & $\begin{array}{c}\text { Composition } \\
\text { of clay (wt\%) }\end{array}$ & $\begin{array}{c}\text { Composition of } \\
\text { coal ash (wt\%) }\end{array}$ \\
\hline $\mathrm{SiO}_{2}$ & 10.10 & 57.60 & 46.83 \\
$\mathrm{Al}_{2} \mathrm{O}_{3}$ & 3.16 & 14.65 & 38.86 \\
$\mathrm{Fe}_{2} \mathrm{O}_{3}$ & 69.78 & 6.59 & 4.66 \\
$\mathrm{CaO}$ & 4.97 & 11.47 & 4.65 \\
$\mathrm{MgO}$ & 1.95 & 2.32 & 0.49 \\
$\mathrm{~K}_{2} \mathrm{O}$ & 0.52 & 4.23 & 1.08 \\
\hline
\end{tabular}

Ceramic, as a kind of lightweight aggregate, is often used to produce concrete mixtures. It is common to use clay producing ceramic nowadays [23], but it requires too much natural resources. The total lightweight aggregate output in China in 2004 is about 420 million $\mathrm{m}^{3}$. Therefore, the use of arsenic-containing wastes as a possible substitute of clay has the potential to provide plenty of raw materials while reducing the consumption of clay. At the same time, the environmental impact caused by arsenic-containing wastes can also be reduced. Earlier studies on making lightweight aggregate from wastes focused mainly on using sewage sludge [24-26] and fly ash [27, 28] as an additive material to clay, but few are particularly devoted to the sintering of arsenic-containing wastes and related mechanisms. During sintering, many reactions and transformations will happen in phyllosilicates and the accompanying minerals, like quartz, calcite, feldspar, hematite, and dolomite, which result in the formation of various crystalline phases. All these transformations and products play an important role in volatilization release and leaching of arsenic.

The aim of this work is to study the volatilization release and leaching of arsenic under different sintering conditions, including sintering temperature and sintering time, such as arsenic volatilization rate, as well as the arsenic leaching behavior of the sintered products. Besides, the reaction mechanism of As in sintering is analyzed by mineralogy and the microstructure of sintered products.

\section{Materials and Methods}

2.1. Sintering Lightweight Aggregates. As-containing residues in this study were obtained from a chemical plant in Henan province, which produced sulfuric acid through sintering pyrite containing As at high temperature, and other materials, such as clay and coal ash, were collected from a cement plant in Beijing (as shown in Table 1). The size distribution of residues was as follows: $41.71 \%$ were 20 mesh $<x<100$ mesh and $46.19 \%$ were $x>100$ mesh.

As-containing residues, clay, and coal ash were mixed together. Cylindrical specimens with a diameter of $10 \mathrm{~mm}$ and a weight of $2 \mathrm{~g}$ were prepared by uniaxial pressing of $10 \mathrm{MPa}$ and subsequently sintered in an electric kiln with sintering temperatures ranging from 1000 to $1350^{\circ} \mathrm{C}$ for 15 , 30,45 , and $60 \mathrm{~min}$, respectively. The specimens were taken

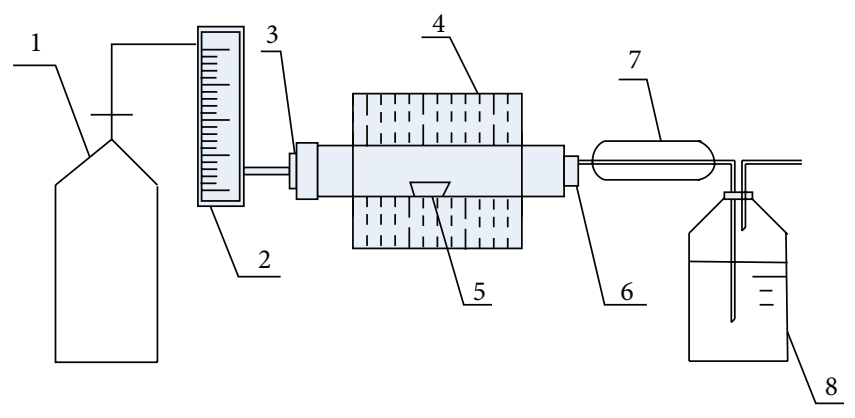
(1) Cylinders
(2) Flowmeter
(5) Crucible
(3) Intakes
(6) Corundum furnace
(4) Sintering furnace
(7) Condenser
(8) Scrubber tank

FIgure 1: The structure of sintering device.

out and cooled at room temperature. A ramp rate of $9^{\circ} \mathrm{C} / \mathrm{min}$ was used.

2.2. Characterization. Heavy metals in residues and in sintered products were determined according to an ASTM method after the samples were digested [29]. The elements were measured by inductively coupled plasma mass spectrometry (ICP-MS, 7500Cs, Agilent Technologies) [30].

Fixed rate of As was defined as the ratio of As weight in products after sintering to that before.

The leaching toxicity of heavy metals in residues and sintered products was analyzed with horizontal vibration extraction procedure (HVEP) [31] and toxicity characteristic leaching procedure (TCLP) [32], respectively. HVEP adopted deionized water as extractant and TCLP used 1\# extractant, that is, mixed $\mathrm{CH}_{3} \mathrm{COOH} / \mathrm{NaOH}$ solution with $\mathrm{pH}=4.93$. The leaching solution was filtrated with $0.45 \mathrm{um}$ millipore filter and tested by inductively coupled plasma mass spectrometry (ICP-MS, 7500Cs, Agilent Technologies).

$\mathrm{Si}, \mathrm{Ca}, \mathrm{Mg}, \mathrm{Fe}, \mathrm{Al}$, and $\mathrm{K}$ contents were determined using an X-ray fluorescence spectrometer (XRF, Shimadzu Lab Center XRF-1700, Japan).

X-ray diffraction (XRD, Seimens O8DISCOVER) using $40 \mathrm{~mA}$ and $40 \mathrm{kV} \mathrm{Cu}$ K_radiation was used for the research of crystalline phases in sintered products. The crystalline phases were identified by comparing the intensities and the positions of the Bragg peaks with the data files of the Joint Committee on Powder Diffraction Standards (JCPDS).

The surface characteristics of sintered products were analyzed visually with scanning electron microscope (SEM). In this study, it adopted KYKY2000 SEM produced by KYKY Technology Development Ltd.; the resolution ratio of secondary electron image point was $6 \mathrm{~nm}$ and the magnification factor was 15 100000 times.

2.3. Experimental Devices. The sintering device was shown in Figure 1. Place the specimen in corundum crucible and then push it into high temperature corundum furnace for sintering. 
TABLE 2: Concentrations and HVEP results of heavy metals in residues.

\begin{tabular}{lcccc}
\hline Heavy metals & $\begin{array}{c}\text { Content of trace } \\
\text { elements }(\mathrm{mg} / \mathrm{kg})\end{array}$ & $\begin{array}{c}\text { HVEP leaching } \\
\text { results of heavy } \\
\text { metals }(\mathrm{mg} / \mathrm{L})\end{array}$ & $\begin{array}{c}\text { Identification Standard for } \\
\text { hazardous wastes [9] (mg/L) }\end{array}$ & $\begin{array}{c}\text { Environmental Quality Standards } \\
\text { for surface water IV [10] (mg/L) }\end{array}$ \\
\hline $\mathrm{Cu}$ & 128.85 & n.d. & 100 & 1.0 \\
$\mathrm{Zn}$ & 1279.24 & n.d. & 100 & 2.0 \\
$\mathrm{Cd}$ & n.d. & n.d. & 1 & 0.005 \\
$\mathrm{~Pb}$ & 212.56 & n.d. & 5 & 0.05 \\
$\mathrm{Cr}$ & n.d. & n.d. & 15 & 0.05 \\
$\mathrm{Be}$ & n.d. & 0.84 & 0.02 & - \\
$\mathrm{Ba}$ & 1046.80 & n.d. & 100 & - \\
$\mathrm{Ni}$ & n.d. & n.d. & 5 & - \\
$\mathrm{Ag}$ & n.d. & 8.35 & 5 & 5 \\
$\mathrm{As}$ & 5552.40 & n.d. & 5 & - \\
$\mathrm{Se}$ & n.d. & & 1 & 0.1 \\
\hline
\end{tabular}

\section{Results and Discussion}

3.1. Properties of As-Containing Residues. Table 1 shows the chemical composition of As-containing residues, clay, and coal ash determined by XRF. The residues contain large amounts of $\mathrm{Fe}_{2} \mathrm{O}_{3}$, with concentrations of $69.78 \%$. The secondary components are $\mathrm{SiO}_{2}(10.10 \%), \mathrm{Al}_{2} \mathrm{O}_{3}(3.16 \%)$, and $\mathrm{CaO}(4.97 \%)$. The contents of other oxides are all less than $2 \%$. To get fine lightweight aggregate, the chemical composition of raw material used should be similar to clay and satisfy the following requirements: $\mathrm{SiO}_{2}$ (48-70\%); $\mathrm{Al}_{2} \mathrm{O}_{3}$ (8-25\%); $\mathrm{Fe}_{2} \mathrm{O}_{3}+\mathrm{FeO}(3-12 \%) ; \mathrm{CaO}+\mathrm{MgO}(1-12 \%)$ [33]. The compositions of residues are not suitable for sintered lightweight aggregate. According to the composition of $\mathrm{Ca}, \mathrm{Si}$, $\mathrm{Al}$, and $\mathrm{Fe}$ as required by sintering lightweight aggregates, Ascontaining residues, clay, and coal ash were mixed together, and the mass ratio was $1: 16: 3$, and following studies are based on the above mass ratio.

Table 2 shows the trace elements in the residues samples determined by ICP-MS. The major heavy metal identified is As, with concentrations of $5552.40 \mathrm{mg} / \mathrm{kg}$. The secondary components are $\mathrm{Zn}(1279.24 \mathrm{mg} / \mathrm{kg})$ and $\mathrm{Ba}(1046.80 \mathrm{mg} / \mathrm{kg})$, while the other heavy metals are all less than $300 \mathrm{mg} / \mathrm{kg}$. The second line of Table 2 gives the HVEP results of heavy metals, and as it indicated, the leaching concentration of As $(8.35 \mathrm{mg} / \mathrm{L})$ does not only exceed China Environmental Quality Standards for surface water [10] $(0.1 \mathrm{mg} / \mathrm{L})$ but also is higher than China Identification Standard for hazardous wastes [9] $(5 \mathrm{mg} / \mathrm{L})$. The leaching concentrations of other heavy metals are all in the range of China Identification Standard for hazardous wastes and China Environmental Quality Standards for surface water.

\subsection{Sintered Products at Different Sintering Temperatures}

\subsubsection{Volatilization of As at Different Sintering Tempera-} tures. Figures 2 and 3 show the total amount of As in sintered products and the fixed rate of As (the specimen was not sintered at $0^{\circ} \mathrm{C}$ ). As indicated in Figure 2, after

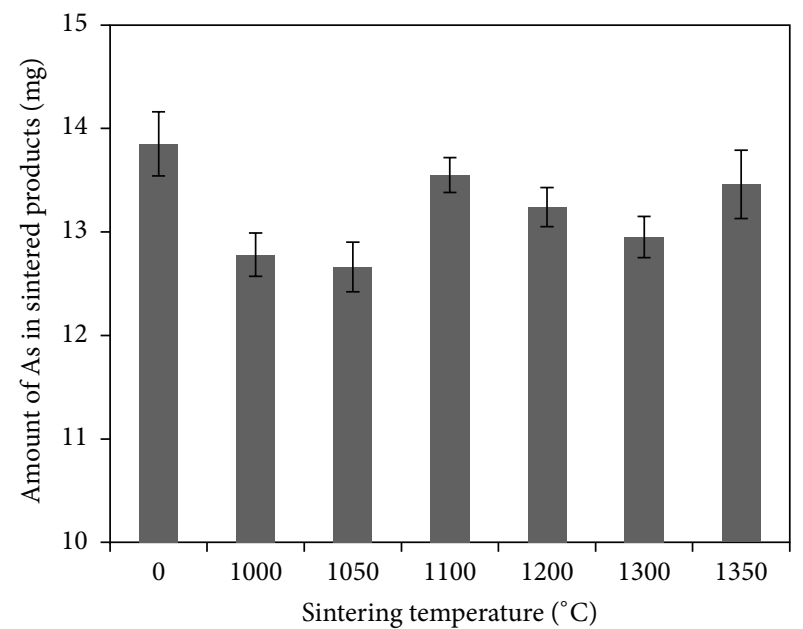

FIGURE 2: Effect of sintering temperature on the total amount of As in sintered products.

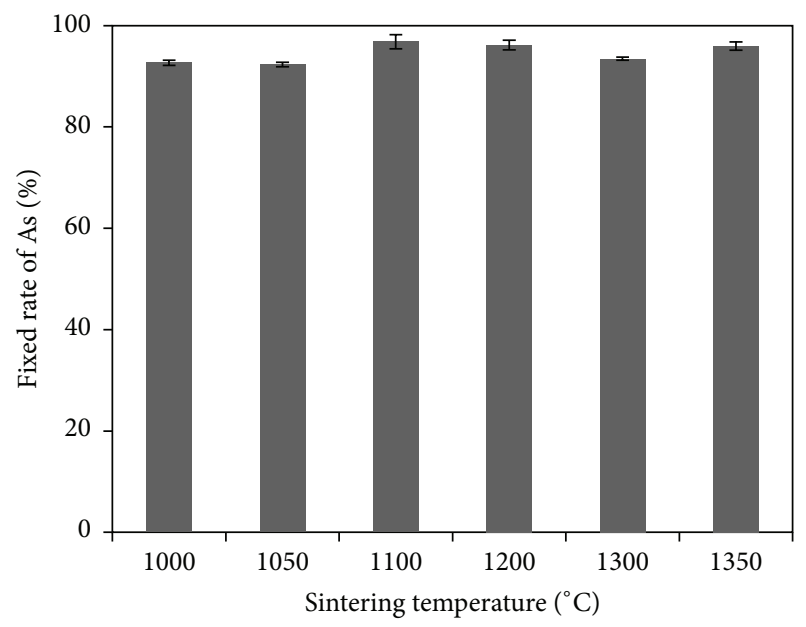

FIgURE 3: The fixed rates of As in sintered products at different sintering temperatures. 
TABLE 3: The As leaching concentration of sintered products at different sintering temperatures.

\begin{tabular}{lcc}
\hline Sintering temperature $\left({ }^{\circ} \mathrm{C}\right)$ & HVEP $(\mathrm{mg} / \mathrm{L})$ & TCLP $(\mathrm{mg} / \mathrm{L})$ \\
\hline $0^{(1)}$ & 0.568 & 0.751 \\
1000 & 0.962 & 1.444 \\
1050 & 0.703 & 1.3 \\
1100 & 0.315 & 0.925 \\
1200 & 0.002 & 0.0017 \\
1300 & 0.001 & 0.0014 \\
1350 & 0.001 & 0.0008 \\
\hline
\end{tabular}

${ }^{(1)}$ The specimen was not sintered at $0^{\circ} \mathrm{C}$.

sintering at different temperatures, the total amount of As was reduced (12.64 13.46 mg) compared with that before sintering $(13.65 \mathrm{mg})$, indicating that arsenic was volatilized during sintering. Figure 3 shows that the fixed rates of As in sintered products were high $(92.58 \% \sim 98.62 \%)$ at different sintering temperatures. Thus, the volatilization rate of As was low during sintering and above $90 \%$ As was fixed in sintered products. Figure 3 also reveals that the volatilization rate of As does not have significant relationship with sintering temperatures between 1000 and $1350^{\circ} \mathrm{C}$.

3.2.2. As Leaching Behavior of Sintered Products at Different Sintering Temperatures. Leaching toxicity test is the most common method to test the characteristics of heavy metal released into the environment. In this study, HVEP and TCLP were used to survey the characteristics of As leaching of the sintered products.

Table 3 lists the As leaching concentration of sintered products at different sintering temperatures. It indicated that with HVEP, as the sintering temperature increased to $1000^{\circ} \mathrm{C}$, the leaching concentration was enhanced significantly, from $0.568 \mathrm{mg} / \mathrm{L}$ to $0.962 \mathrm{mg} / \mathrm{L}$, indicating that arsenic mineral phase in sintered products was changed and As in the sintered products was more easily released into the environment. When the temperature continued to rise to $1200^{\circ} \mathrm{C}$, the As leaching concentration decreased significantly to $0.002 \mathrm{mg} / \mathrm{L}$. With TCLP, a similar phenomenon was shown. From room temperature to $1000^{\circ} \mathrm{C}$, As leaching concentration in sintered products increased from $0.751 \mathrm{mg} / \mathrm{L}$ to $1.444 \mathrm{mg} / \mathrm{L}$, and as the temperature raised to $1200^{\circ} \mathrm{C}$, As leaching concentration decreased significantly to $0.0017 \mathrm{mg} / \mathrm{L}$. As the temperature continued to rise, the concentration changed a little. It is concluded that in order to reach lower leaching concentration of As, the sintering temperature must be higher than $1200^{\circ} \mathrm{C}$. So, the following studies are based on the sintering temperature of $1200^{\circ} \mathrm{C}$.

\subsection{Sintered Products at Different Sintering Times}

3.3.1. Volatilization of As at Different Sintering Times. With $2000 \mathrm{~mL} / \mathrm{min}$ air inflow and $1200^{\circ} \mathrm{C}$ sintering temperature, specimen was sintered for different times. As shown by Figure 4 (the specimen was not sintered at $0 \mathrm{~min}$ ), the total amount of As was lower after sintering than before. Figure 5

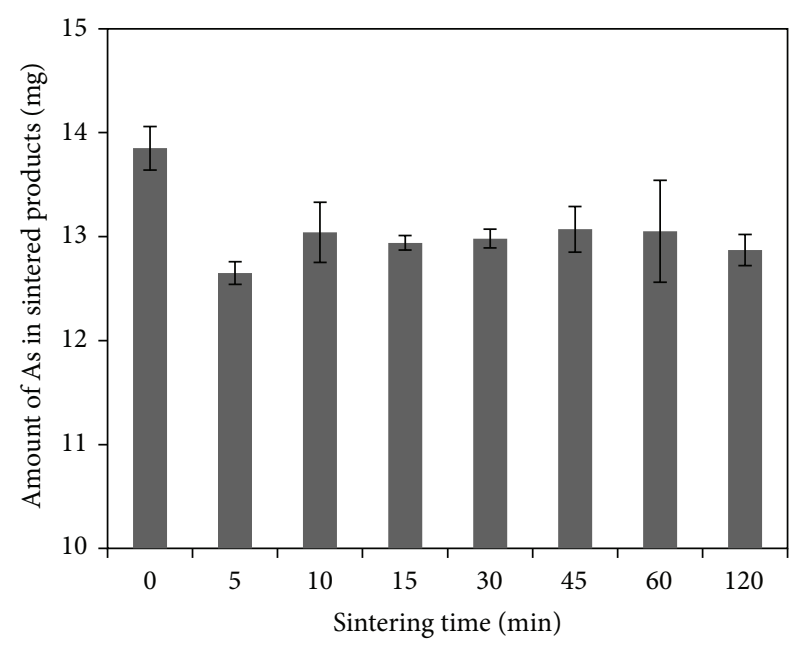

FIGURE 4: Effect of sintering time on the total amount of As in sintered products.

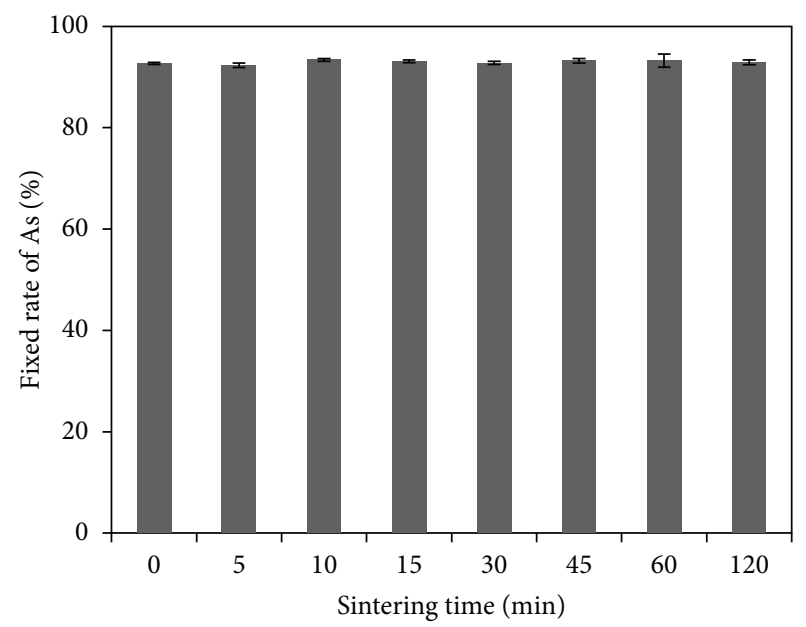

FIgURE 5: The fixed rates of As in sintered products at different sintering times.

shows the fixed rates of As in sintered products for different sintering times. As indicated by the figure, after $5 \mathrm{~min}$ sintering, the fixed rate of As was up to $92.53 \%$, and as the time extended, the rates did not change correspondingly. More than $90 \%$ of As remained in sintered products. It is concluded that arsenic volatilization occurred within 5 minutes and after 5 min sintering arsenic volatilization changed a little.

\subsubsection{As Leaching Behavior of Sintered Products at Different} Sintering Times. Table 4 displays the leaching concentration of As at different sintering times at the conditions of $10 \mathrm{MPa}$ molding pressure, $2000 \mathrm{~mL} / \mathrm{min}$ air inflow, and $1200^{\circ} \mathrm{C}$ sintering temperature. As indicated by the table, with HVEP, the longer the sintering time, the lower the As leaching concentration. At $45 \mathrm{~min}$, the concentration was reduced to $0.003 \mathrm{mg} / \mathrm{L}$. With TCLP, at $30 \mathrm{~min}$, the concentration reduced to $0.0023 \mathrm{mg} / \mathrm{L}$ and as the time extended $>30 \mathrm{~min}$, the concentration changed a little. It is concluded that the 
TABLE 4: The As leaching concentration of sintered products for different sintering times.

\begin{tabular}{lcc}
\hline Sintering time $(\mathrm{min})$ & HVEP $(\mathrm{mg} / \mathrm{L})$ & TCLP $(\mathrm{mg} / \mathrm{L})$ \\
\hline $0^{(1)}$ & 0.568 & 0.751 \\
5 & 0.482 & 1.239 \\
10 & 0.317 & 0.554 \\
15 & 0.108 & 0.194 \\
30 & 0.086 & 0.0023 \\
45 & 0.003 & 0.0011 \\
60 & 0.002 & 0.0017 \\
120 & n.d. & 0.0009 \\
\hline
\end{tabular}

${ }^{(1)}$ The specimen was not sintered.

TABLE 5: $\Delta G$ at different sintering temperatures.

\begin{tabular}{lcccc}
\hline \multirow{2}{*}{$\left({ }^{\circ} \mathrm{C}\right)$} & \multicolumn{4}{c}{$G(\mathrm{kcal})$} \\
& Equation (1) & Equation (2) & Equation (3) & Equation (4) \\
\hline 600 & -2004.27 & -129.25 & -107.29 & -71.83 \\
800 & -1919.60 & -116.56 & -101.15 & -57.67 \\
1000 & -1832.31 & -103.80 & -94.99 & -43.48 \\
1100 & -1787.48 & -97.42 & -91.95 & -36.45 \\
1200 & -1741.82 & -91.05 & -88.94 & -29.48 \\
1300 & -1695.31 & -84.70 & -85.97 & -22.59 \\
\hline
\end{tabular}

sintering time must be no less than $45 \mathrm{~min}$ for the lower leaching concentration of As. So, some studies are based on the condition of $45 \mathrm{~min}$ in the following text.

3.4. Structural Characterization. Figure 6 shows the XRD data of sintered products at different sintering temperatures. Hematite $\left(\mathrm{Fe}_{2} \mathrm{O}_{3}\right)$, calcium sulfite $\left(\mathrm{CaSO}_{3}\right)$, sulfur arsenic iron $(\mathrm{FeAsS})$, quartz $\left(\mathrm{SiO}_{2}\right)$, and arsenic trioxide $\left(\mathrm{As}_{2} \mathrm{O}_{3}\right)$ are detected originally in the specimen before sintering. Comparing the mineral phases before sintering and after sintering at $1000^{\circ} \mathrm{C}$, it was found that the intensities of the peaks associated with $\mathrm{FeAsS}, \mathrm{CaSO}_{3}$, and $\mathrm{As}_{2} \mathrm{O}_{3}$ decrease as sintering temperature increases, and the peak of $\mathrm{AlAsO}_{4}$, $\mathrm{Ca}_{3}\left(\mathrm{AsO}_{4}\right)_{2}, \mathrm{MgO} \cdot \mathrm{SiO}_{2}$, and $\mathrm{Al}_{2} \mathrm{O}_{3} \cdot \mathrm{SiO}_{2}$ mineral phases was enhanced. It is suggested that when the sintering temperature increases to $1000^{\circ} \mathrm{C}$, several reactions, as follows, take place. When the sintering temperature increased from $1000^{\circ} \mathrm{C}$ to $1200^{\circ} \mathrm{C}$, material structures in the sintered products were not changed significantly:

$$
\begin{gathered}
3 \mathrm{FeAsS}+7.25 \mathrm{O}_{2}=\mathrm{Fe}_{3} \mathrm{O}_{4}+1.5 \mathrm{As}_{2} \mathrm{O}_{3}+3 \mathrm{SO}_{2} \\
3 \mathrm{CaO}+\mathrm{As}_{2} \mathrm{O}_{3}+\mathrm{O}_{2}=\mathrm{Ca}_{3}\left(\mathrm{AsO}_{4}\right)_{2} \\
\mathrm{Al}_{2} \mathrm{O}_{3}+\mathrm{As}_{2} \mathrm{O}_{3}+\mathrm{O}_{2}=2 \mathrm{AlAsO}_{4} \\
\mathrm{Fe}_{3} \mathrm{O}_{4}+1.5 \mathrm{As}_{2} \mathrm{O}_{3}+1.75 \mathrm{O}_{2}=3 \mathrm{FeAsO}_{4} \\
2 \mathrm{CaSO}_{3}+\mathrm{O}_{2}=2 \mathrm{CaSO}_{4}
\end{gathered}
$$

Table 5 shows the results of Gibbs-free energy $(\Delta G)$ calculation in the heating of FeAsS, $-1690 \mathrm{kcal} \sim-2004 \mathrm{kcal}$, which indicated that the reaction was spontaneously. In this analysis, FeAsS was reacted as (1), $\mathrm{As}_{2} \mathrm{O}_{3}$ was generated, and FeAsS disappeared. $\mathrm{As}_{2} \mathrm{O}_{3}$ can react with $\mathrm{Ca}, \mathrm{Fe}$, and $\mathrm{Al}$ spontaneously as (2), (3), and (4). When the temperature was lower than $1200^{\circ} \mathrm{C}$, the reaction sequence was $\mathrm{CaO}>\mathrm{Al}_{2} \mathrm{O}_{3}>$ $\mathrm{Fe}_{3} \mathrm{O}_{4}$, and thus $\mathrm{Ca}_{3}\left(\mathrm{AsO}_{4}\right)_{2}$ and $\mathrm{AlAsO}_{4}$ were generated when it was less than $1200^{\circ} \mathrm{C}$, which enhanced the phase peak.

$\mathrm{FeAsS}$ is natural mineral, and it is poorly soluble in water. $\mathrm{Ca}_{3}\left(\mathrm{AsO}_{4}\right)_{2}$ is slightly soluble in water and its solubility is between 0.01 and $12.6 \mathrm{mg} / \mathrm{L}$ in water of different $\mathrm{pH}$. arsenic trioxide is soluble in water. Thus, as the sintering temperature increased to $1000^{\circ} \mathrm{C}$ from room temperature, the leaching concentration of As increased correspondingly.

3.5. SEM Microstructure Observation of Sintered Products. Figure 7 shows the SEM of sintered products at different sintering temperatures. At $800^{\circ} \mathrm{C}$, the sintered body was loosely accumulated as particles; at $1000^{\circ} \mathrm{C}$, the specimen began to melt; at $1200^{\circ} \mathrm{C}$, the surface of sintered products appeared to be bonded and small amount of liquid was generated. Liquid phase made particles bond with each other; $\mathrm{Ca}_{3}\left(\mathrm{AsO}_{4}\right)_{2}$ was enveloped in molten state and transformed into chemical bond of $\mathrm{Si}-\mathrm{Ca}$ arsenate, which greatly reduced the leaching concentration of As.

\section{Conclusions}

(1) In the process of sintering As-containing residues at high temperatures, the total amount of As in sintered products changed insignificantly, and the fixed rate of As was higher than $90 \%$ at $800 \sim 1300^{\circ} \mathrm{C}$.

(2) Sintering temperature had significant impact on the leaching characteristics of As in sintered products. With HVEP, the higher the sintering temperature, the lower the As leaching concentration. At $1200^{\circ} \mathrm{C}$, the leaching concentration of As was $0.002 \mathrm{mg} / \mathrm{L}$. In TCLP, the leaching concentration of As was the lowest at $1200^{\circ} \mathrm{C}, 0.0017 \mathrm{mg} / \mathrm{L}$. Thus from the aspect of environmental security, the best sintering temperature is $1200^{\circ} \mathrm{C}$.

(3) Sintering time also had significant impact on the leaching characteristics of As in sintered products. With HVEP, the longer the sintering time, the lower the As leaching concentration. From $0 \mathrm{~min}$ to $45 \mathrm{~min}$, the concentration was reduced significantly from $0.568 \mathrm{mg} / \mathrm{L}$ to $0.003 \mathrm{mg} / \mathrm{L}$. With TCLP, at $30 \mathrm{~min}$, the concentration reduced to $0.0023 \mathrm{mg} / \mathrm{L}$ and as the time extended $>30 \mathrm{~min}$, the concentration changed a little. Thus the sintering time must be no less than $45 \mathrm{~min}$ for the lower leaching concentration of As.

(4) In the sintering of As-containing residues, if it is lower than $1000^{\circ} \mathrm{C}$, FeAsS will be oxidized and generate $\mathrm{As}_{2} \mathrm{O}_{3}$, which will react with $\mathrm{Ca}, \mathrm{Al}$, and $\mathrm{Fe}$ to generate corresponding compounds, mainly $\mathrm{Ca}_{3}\left(\mathrm{AsO}_{4}\right)_{2}$ and $\mathrm{AlAsO}_{4}$. FeAsS is poorly soluble in water while $\mathrm{Ca}_{3}\left(\mathrm{AsO}_{4}\right)_{2}$ is slightly soluble in water. Thus, when it is lower than $1000^{\circ} \mathrm{C}$, the leaching concentration of As in sintered products will increase. 


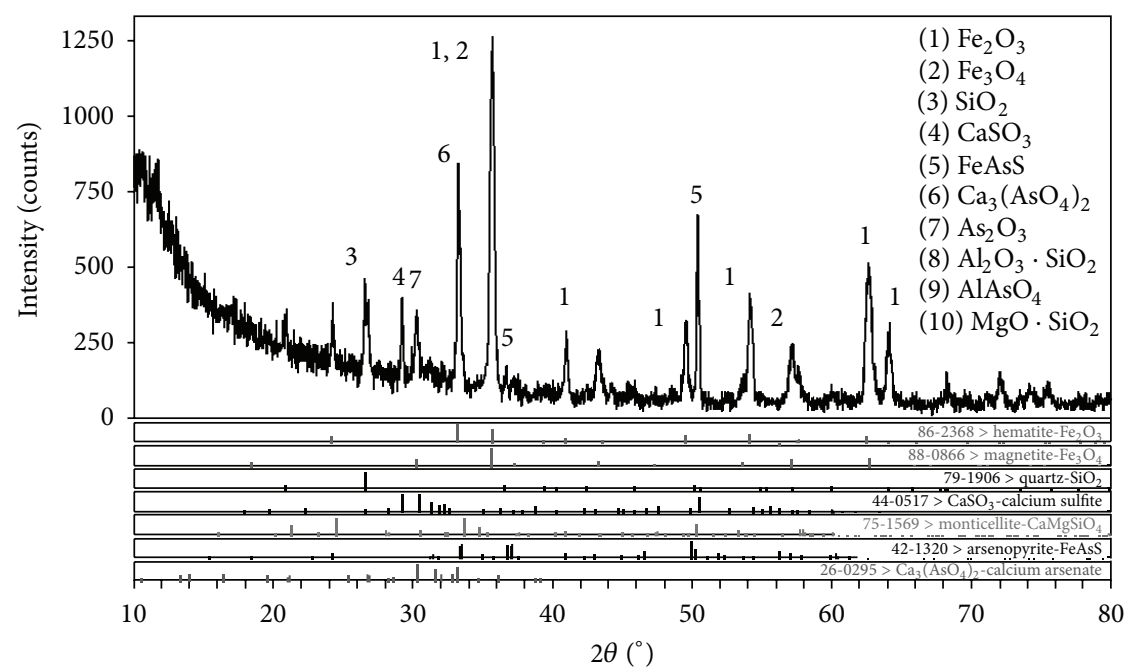

(a) X-ray diffraction of the specimen before sintering

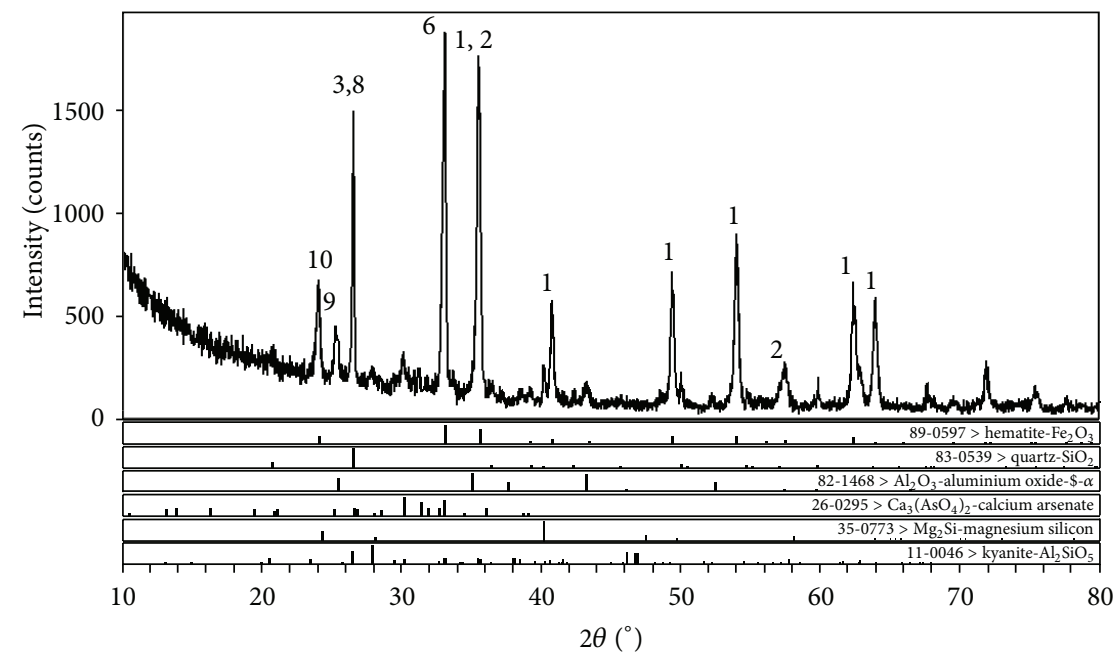

(b) X-ray diffraction of sintered products at $1000^{\circ} \mathrm{C}$

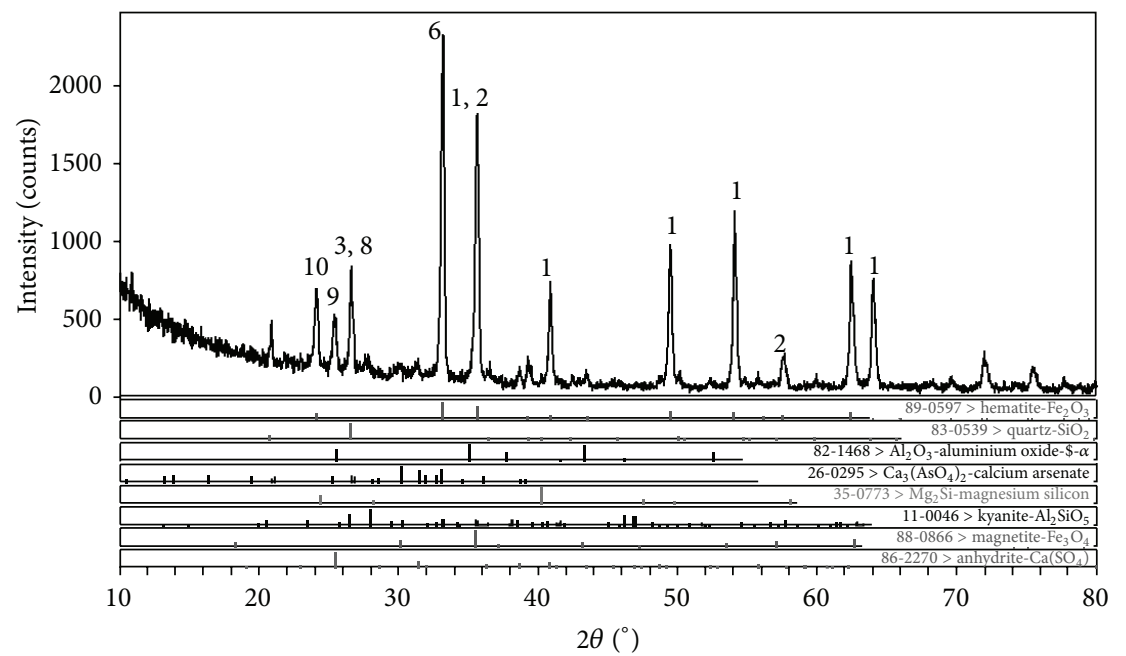

(c) X-ray diffraction of sintered products at $1200^{\circ} \mathrm{C}$

FIGURE 6: X-ray diffraction of sintered products at different sintering temperatures. 


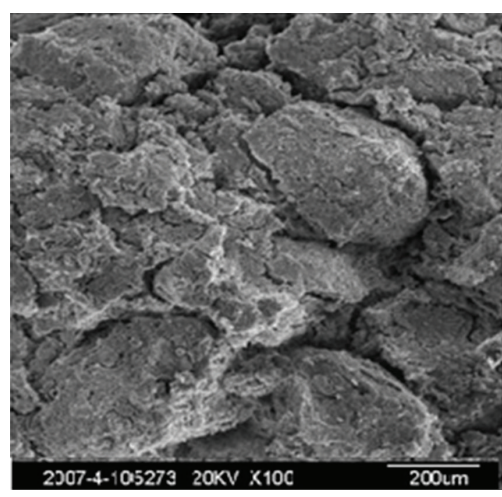

$800^{\circ} \mathrm{C}-60 \min (\times 100)$

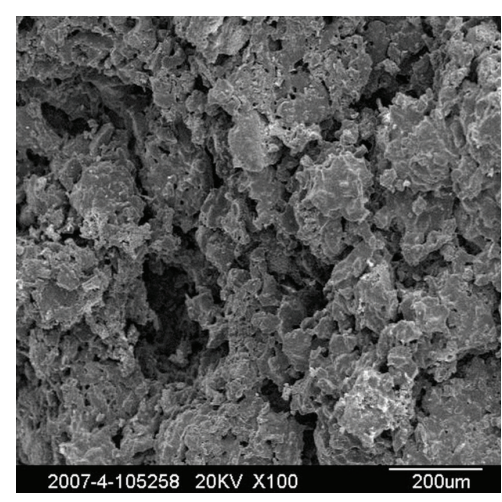

$1000^{\circ} \mathrm{C}-60 \min (\times 100)$

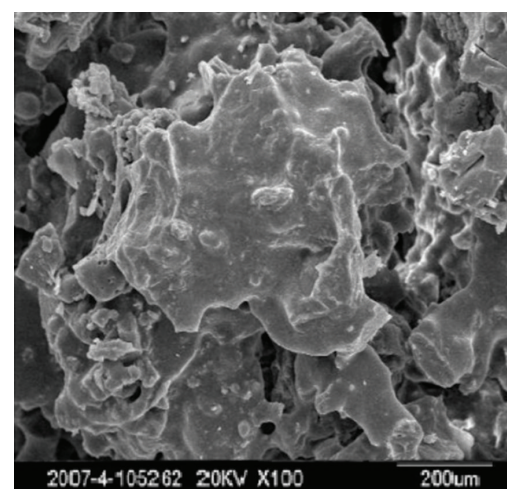

$1200^{\circ} \mathrm{C}-60 \min (\times 100)$

FIGURE 7: SEM of sintered products at different sintering temperatures.

(5) When the sintering temperature is up to $1200^{\circ} \mathrm{C}$, sintered products will be molten; $\mathrm{Ca}_{3}\left(\mathrm{AsO}_{4}\right)_{2}$ was enveloped in molten state and transformed into chemical bond of $\mathrm{Si}-\mathrm{Ca}$ arsenate, which greatly reduces the leaching concentration of As.

\section{Conflict of Interests}

The authors declare that there is no conflict of interests regarding the publication of this paper.

\section{Acknowledgment}

Project is supported by the National Natural Science Foundation of China (Grant no. 21107102).

\section{References}

[1] P. B. Tchounwou, J. A. Centeno, and A. K. Patlolla, "Arsenic toxicity, mutagenesis, and carcinogenesis - a health risk assessment and management approach," Molecular and Cellular Biochemistry, vol. 255, no. 1-2, pp. 47-55, 2004.

[2] T. Yoshida, H. Yamauchi, and G. Fan Sun, "Chronic health effects in people exposed to arsenic via the drinking water: dose-response relationships in review," Toxicology and Applied Pharmacology, vol. 198, no. 3, pp. 243-252, 2004.

[3] A. J. Monhemius and P. M. Swash, "Removing and stabilizing As from copper refining circuits by hydrothermal processing," Journal of Hazardous Materials, vol. 51, no. 9, pp. 30-33, 1999.

[4] M. L. Pierce and C. B. Moore, "Adsorption of arsenite and arsenate on amorphous iron hydroxide," Water Research, vol. 16, no. 7, pp. 1247-1253, 1982.

[5] P. H. Masscheleyn, R. D. Delaune, and W. H. Patrick Jr., "Effect of redox potential and $\mathrm{pH}$ on arsenic speciation and solubility in a contaminated soil," Environmental Science and Technology, vol. 25, no. 8, pp. 1414-1419, 1991.

[6] G. Ona-Nguema, G. Morin, F. Juillot, G. Calas, and G. E. Brown Jr., "EXAFS analysis of arsenite adsorption onto two-line ferrihydrite, hematite, goethite, and lepidocrocite," Environmental Science and Technology, vol. 39, no. 23, pp. 9147-9155, 2005.

[7] P. G. Smith, I. Koch, R. A. Gordon, D. F. Mandoli, B. D. Chapman, and K. J. Reimer, "X-ray absorption near-edge structure analysis of arsenic species for application to biological environmental simples," Environmental Science and Technology, vol. 39, no. 1, pp. 248-254, 2005.

[8] J. G. Parsons, M. V. Aldrich, and J. L. Gardea-Torresdey, "Environmental and biological applications of extended X-ray absorption fine structure (EXAFS) and X-ray absorption near edge structure (XANES) spectroscopies," Applied Spectroscopy Reviews, vol. 37, no. 2, pp. 187-222, 2002.

[9] "Identification standard for hazardous wastes," GB5085.3-2007.

[10] "Environmental quality standards for surface water," GB38382002.

[11] U. Förstner and I. Haase, "Geochemical demobilization of metallic pollutants in solid waste-implications for arsenic in waterworks sludges," Journal of Geochemical Exploration, vol. 62, no. 1-3, pp. 29-36, 1998.

[12] C. Shi and R. Spence, "Designing of cement-based formula for solidification/stabilization of hazardous, radioactive, and mixed wastes," Critical Reviews in Environmental Science and Technology, vol. 34, no. 4, pp. 391-417, 2004.

[13] M. Leist, R. J. Casey, and D. Caridi, “The fixation and leaching of cement stabilized arsenic," Waste Management, vol. 23, no. 4, pp. 353-359, 2003.

[14] D. Dermatas, D. H. Moon, N. Menounou, X. Meng, and R. Hires, "An evaluation of arsenic release from monolithic solids using a modified semi-dynamic leaching test," Journal of Hazardous Materials, vol. 116, no. 1-2, pp. 25-38, 2004.

[15] T. S. Singh and K. K. Pant, "Solidification/stabilization of arsenic containing solid wastes using portland cement, fly ash and polymeric materials," Journal of Hazardous Materials, vol. 131, no. 1-3, pp. 29-36, 2006.

[16] D. H. Moon and D. Dermatas, "Arsenic and lead release from fly ash stabilized/solidified soils under modified semi-dynamic leaching conditions," Journal of Hazardous Materials, vol. 141, no. 2, pp. 388-394, 2007.

[17] C. Vandecasteele, V. Dutré, D. Geysen, and G. Wauters, "Solidification/stabilisation of arsenic bearing fly ash from the metallurgical industry. Immobilisation mechanism of arsenic," Waste Management, vol. 22, no. 2, pp. 143-146, 2002.

[18] I.-H. Yoon, D. H. Moon, K.-W. Kim, K.-Y. Lee, J.-H. Lee, and M. G. Kim, "Mechanism for the stabilization/solidification of arsenic-contaminated soils with Portland cement and cement kiln dust," Journal of Environmental Management, vol. 91, no. 11, pp. 2322-2328, 2010. 
[19] D. H. Moon, M. Wazne, I.-H. Yoon, and D. G. Grubb, "Assessment of cement kiln dust (CKD) for stabilization/solidification (S/S) of arsenic contaminated soils," Journal of Hazardous Materials, vol. 159, no. 2-3, pp. 512-518, 2008.

[20] V. Dutré and C. Vandecasteele, "Immobilization mechanism of arsenic in waste solidified using cement and lime," Environmental Science and Technology, vol. 32, no. 18, pp. 2782-2787, 1998.

[21] D. H. Moon, D. Dermatas, and N. Menounou, "Arsenic immobilization by calcium-arsenic precipitates in lime treated soils," Science of the Total Environment, vol. 330, no. 1-3, pp. 171-185, 2004.

[22] V. Dutré, C. Kestens, J. Schaep, and C. Vandecasteele, "Study of the remediation of a site contaminated with arsenic," Science of the Total Environment, vol. 220, no. 2-3, pp. 185-194, 1998.

[23] M. M. Jordán, A. Boix, T. Sanfeliu, and C. De La Fuente, "Firing transformations of cretaceous clays used in the manufacturing of ceramic tiles," Applied Clay Science, vol. 14, no. 4, pp. 225-234, 1999.

[24] X. Wang, Y. Jin, Z. Wang, R. B. Mahar, and Y. Nie, "A research on sintering characteristics and mechanisms of dried sewage sludge," Journal of Hazardous Materials, vol. 160, no. 2-3, pp. 489-494, 2008.

[25] X. Wang, Y. Jin, Z. Wang, Y. Nie, Q. Huang, and Q. Wang, "Development of lightweight aggregate from dry sewage sludge and coal ash," Waste Management, vol. 29, no. 4, pp. 1330-1335, 2009.

[26] J.-H. Tay and K.-Y. Show, "Resource recovery of sludge as a building and construction material-a future trend in sludge management," Water Science and Technology, vol. 36, no. 11, pp. 259-266, 1997.

[27] F. Liu, J. Liu, Q. Yu, Y. Jin, and Y. Nie, "Leaching characteristics of heavy metals in municipal solid waste incinerator fly ash," Journal of Environmental Science and Health, Part A, vol. 40, no. 10, pp. 1975-1985, 2005.

[28] F. Liu, J.-G. Liu, Q.-F. Yu, and Y.-F. Nie, "Chemical speciation and mobility of heavy metals in municipal solid waste incinerator fly ash," Journal of Environmental Sciences, vol. 16, no. 6, pp. 885-888, 2004.

[29] "Standard test methods for determination of trace elements in coal, coke, and combustion residues from coal utilization processes by inductively coupled plasma atomic emission spectrometry, inductively coupled plasma mass spectrometry, and graphite furnace atomic absorption spectrometry," ASTM Standard Method D 6357-00a.

[30] X. Wan, W. Wang, T. Ye, Y. Guo, and X. Gao, "A study on the chemical and mineralogical characterization of MSWI fly ash using a sequential extraction procedure," Journal of Hazardous Materials, vol. 134, no. 1-3, pp. 197-201, 2006.

[31] "Test method standard for leaching toxicity of solid wasteshorizontal vibration extraction procedure," GB5086.2, 1997.

[32] U.S. Environmental Protection Agency, Toxicity Characteristics Leaching Procedure, Method 1311, USEPA, Washington, DC, USA, 1992.

[33] C. M. Riley, "Relation of chemical properties to bloating of clays," The American Ceramic Society, vol. 34, pp. 121-128, 1951. 

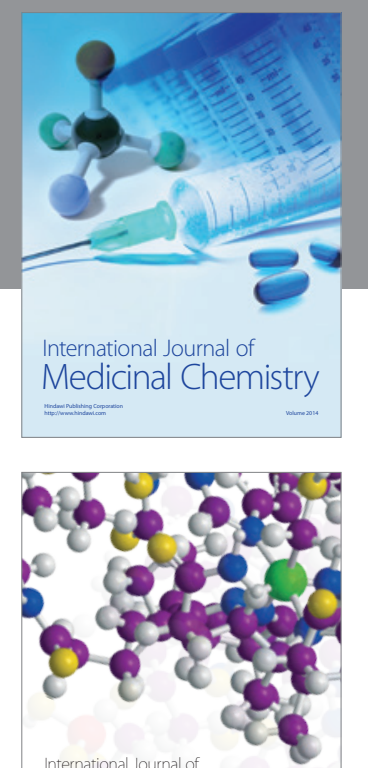

\section{Carbohydrate} Chemistry

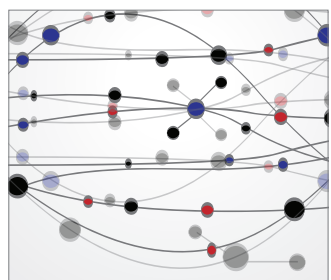

The Scientific World Journal
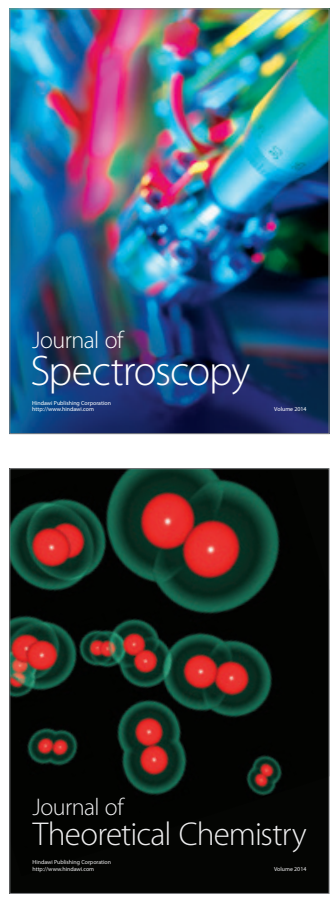
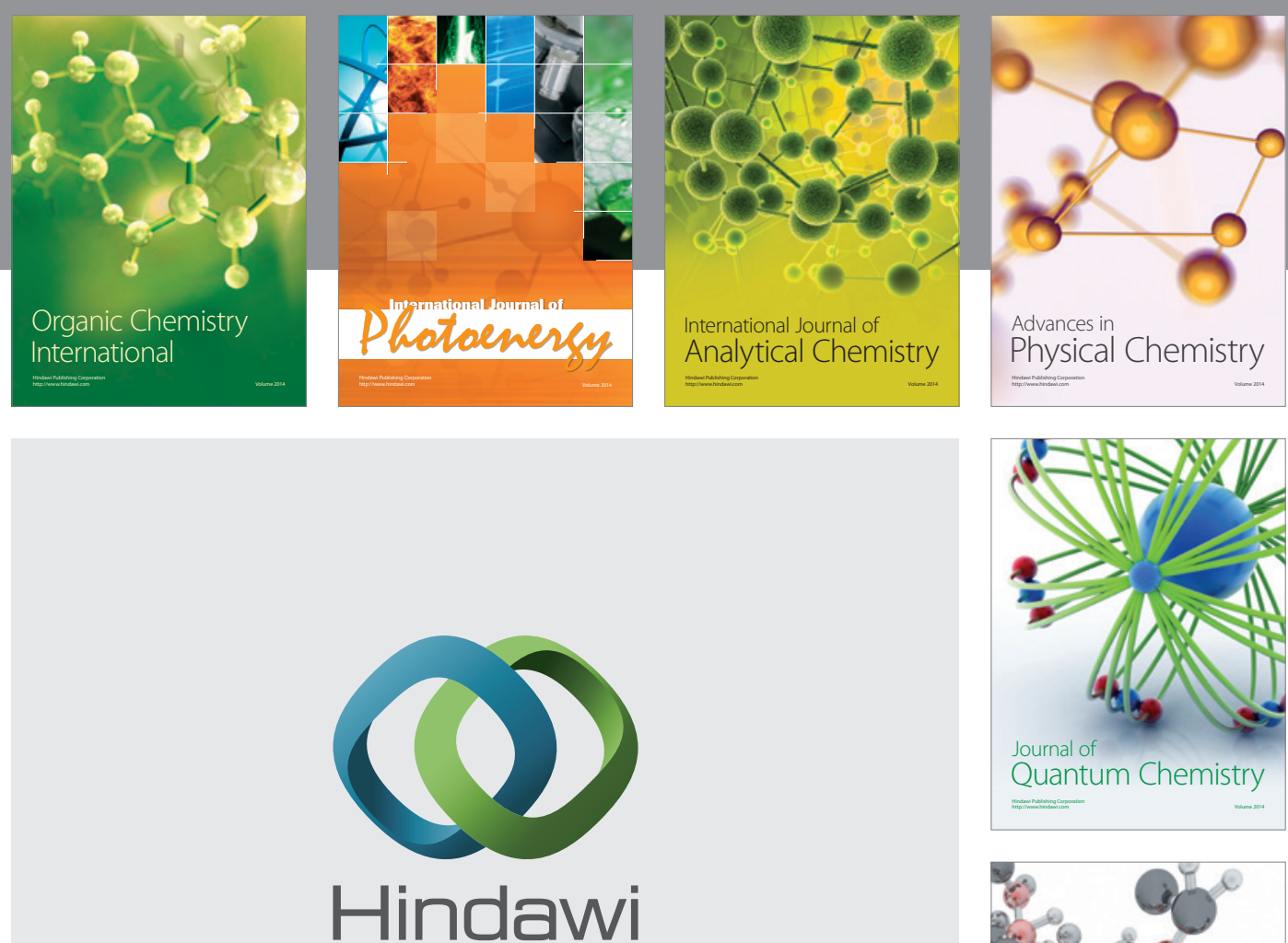

Submit your manuscripts at

http://www.hindawi.com

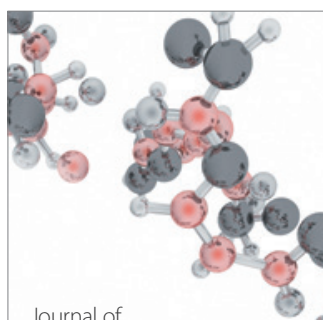

Analytical Methods

in Chemistry

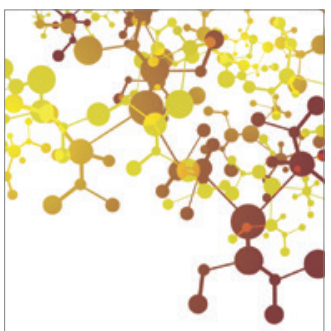

Journal of

Applied Chemistry

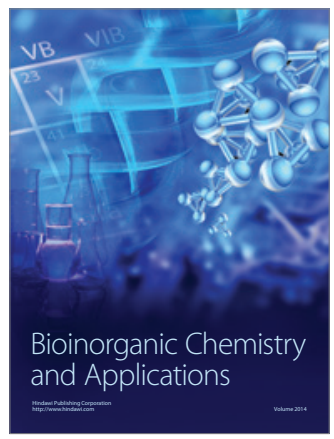

Inorganic Chemistry
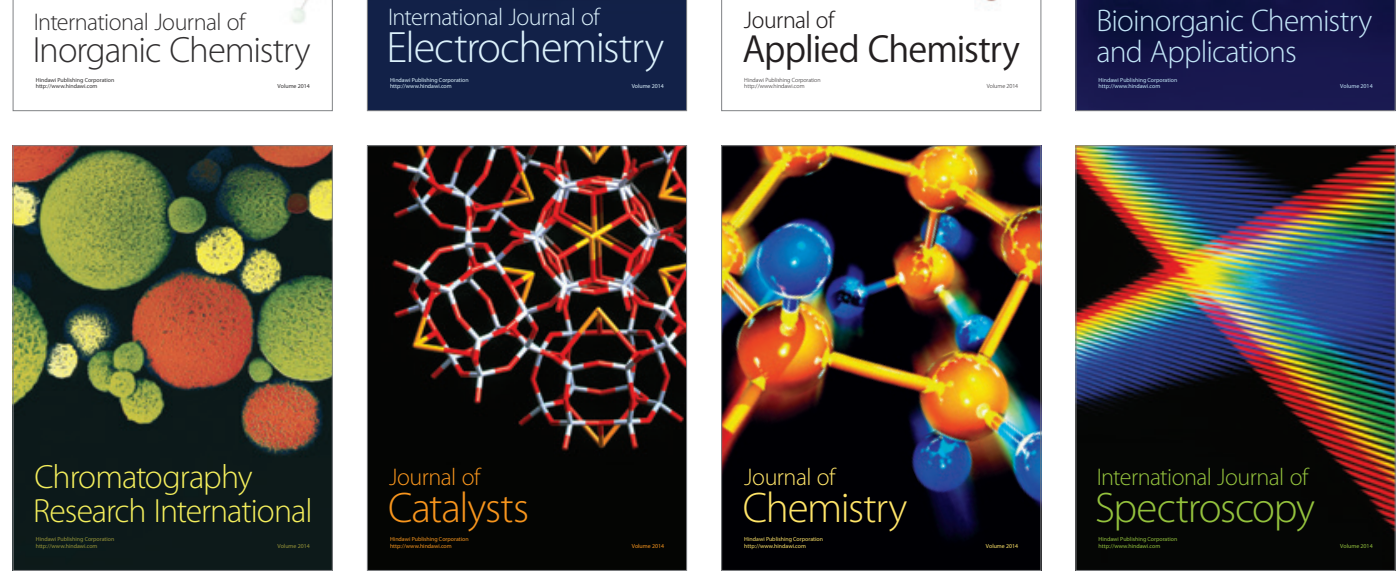